\title{
UJI AKTIVITAS ANTIBAKTERI DAN ANTI-UV DARI EKSTRAK ETIL ASETAT ISOLAT JAMUR AFBK 5C YANG BERSIMBION DENGAN ASCIDIA Sigilina sp. DARI PERAIRAN PULAU BANGKA
}

\author{
(Antibacterial and Anti-UV Activity Test from Ethyl Acetate Extract of fungus isolate \\ AFBK 5c that Symbiont with Ascidia Sigilina sp. from Bangka Island)
}

\author{
Veisy N. M. Tamburian ${ }^{1 *}$, Deske A. Sumilat ${ }^{2}$, Chatrien A. L. Sinjal ${ }^{2}$, Veibe Warouw ${ }^{1}$, Rizald M. \\ Rompas $^{2}$, Hengky Sinjal ${ }^{3}$
}

1. Mahasiswa Program Studi IImu Kelautan, FPIK, UNSRAT Manado

2. Staf Pengajar Program Studi IImu Kelautan, FPIK, UNSRAT Manado

3. Staf Pengajar Program Studi Budidaya Perairan, FPIK UNSRAT Manado

Penulis korespondensi: Veisy N.M. Tamburian; tamburianveisi@gmail.com

\begin{abstract}
Bioactive compounds are toxic compounds produced by organisms for use in self-defense from a wide variety of predators residing in their environment. The aim of the study was to test antibacterial activity and prove the UV-preventing effectiveness of the AFBK $5 \mathrm{c}$ mushroom isolate ethyl acetate extract that is in conjunction with ascidia. This research was conducted for 1 month in two locations, namely for antibacterial testing conducted in the Laboratory of Molecular Biology and Marine Pharmaceuticals, FPIK and for anti-UV testing conducted at the Pharmaceutical Laboratory, FMIPA, UNSRAT. The results showed that; This type of fungus that has been extracted and used is a fungus with the isolate code AFBK $5 \mathrm{c}$ This mushroom is a fungus that is connected with sigilina sp type ascidia. The rough extract of ascidia symbiont mushrooms is obtained from the process of meseration using ethyl acetate, then antibacterial testing of $\mathrm{S}$. aureus and $\mathrm{E}$. coli test bacteria and showing results such as antibacterial activity with an average value in S. aureus 09.00 and $\mathrm{E}$. coli $11.05 \mathrm{~mm}$ which shows that there is antibacterial activity of AFBK $5 c$ fungus isolate against $\mathrm{E}$. coli and $\mathrm{S}$. aureus test bacteria so that it can be said that the symbiont fungus has the potential as an ingredient. manufacture of antibacterial drugs. Furthermore, anti-UV testing, and the results of testing anti-UV compounds using rough extracts of AFBK 5c fungus isolates can produce absorption in UV-B $(\lambda 290-320 \mathrm{~nm})$ and UV-A $(\lambda 320-400 \mathrm{~nm})$ so that it has the potential to be used as an anti-UV material.
\end{abstract}

Keywords: Bioactive Compound, Ascidia, Meceration, Antibacterial, Anti-UV

\section{ABSTRAK}

Senyawa bioaktif adalah senyawa toksik yang dihasilkan oleh organisme untuk digunakan dalam pertahanan diri dari berbagai macam predator yang berada di lingkungannya. Tujuan penelitian ini adalah untuk menguji aktivitas antibakteri dan membuktikan efektivitas mecegah UV dari ekstrak etil asetat isolat jamur AFBK $5 c$ yang bersimbion dengan ascidia. Penelitian ini dilakukan selama 1 bulan di dua lokasi yaitu untuk pengujian antibateri dilaksanakan di Laboratorium Biologi Molekuler dan Farmasitika Laut, FPIK dan untuk pengujian anti-UV dilakukan di Laboratorium Farmasi, FMIPA, UNSRAT. Hasil penelitian menunjukkan bahwa; jenis jamur yang telah diekstrak dan digunakan adalah jamur dengan kode isolat AFBK $5 \mathrm{c}$ Jamur ini adalah jamur yang bersimbion dengan ascidia jenis Sigilina sp. Ekstrak kasar jamur simbion ascidia ini didapatkan dari proses meserasi menggunakan etil asetat, selanjutnya dilakukan pengujian antibakteri terhadap bakteri uji $S$. aureus dan $E$. coli dan menunjukkan hasil seperti aktivitas antibakteri dengan nilai rata-rata pada $S$. aureus 09,00 dan $E$. coli $11,05 \mathrm{~mm}$ yang menunjukkan bahwa terdapat aktivitas antibakteri dari isolat jamur AFBK $5 \mathrm{c}$ terhadap bakteri uji $E$. coli dan $S$. aureus sehingga bisa dikatakan jamur simbion tersebut berpotensi sebagai bahan pembuatan obat antibakteri. Selanjutnya dilakukan pengujian anti-UV, dan hasil dari pengujian senyawa anti-UV menggunakan esktrak kasar isolat jamur AFBK $5 \mathrm{c}$ dapat menghasilkan serapan pada UV-B $(\lambda$ 290-320 nm) dan UV-A ( $\lambda$ 320-400 nm) sehingga berpotensi dijadikan bahan anti UV.

Kata kunci : Senyawa Bioaktif, Ascidia, Meserasi, Antibakteri, Anti-UV 


\section{PENDAHULUAN}

Lingkungan laut merupakan sumber yang besar dari produk alam yang memiliki struktur yang unik yang umumnya terkonsentrasi pada sponge, tunikata, bryozoa, dan moluska yang merupakan organisme yang hidup dalam kolom air. Sejumlah besar dari senyawasenyawa ini menunjukkan aktivitas farmakologi yang kuat dan merupakan kandidat yang menarik untuk bahan obat-obatan baru terutama pada area penelitian antikanker dan antimikroba (Bara dkk., 2015).

Indonesia

memiliki

keanekaragaman hayati laut tinggi yang bukan hanya sebagai sumber makanan, sumber daya laut juga dapat dikembangkan sebagai bahan obat seperti, antikanker, anti jamur, antibakteri dan anti-UV. (Proksch dkk., 2002).

Keanekaragaman hayati laut yang sangat tinggi serta faktor-faktor lingkungan di laut yang juga beragam membuat sumber daya alam laut menarik diteliti untuk mendapatkan produk alami. Sumber daya alam laut merupakan sumber daya hayati yang potensial untuk dikembangkan dan dikelola secara maksimal (Marzuki dkk., 2018).

Beberapa biota laut yang menghasilkan bahan hayati yang memiliki aktivitas biologis diantaranya yaitu spons, ascidia, bryozoa, dan moluska (Proksch $d k k$., 2002).

Ascidia merupakan avertebrata di ekosistem terumbu karang yang banyak menghasilkan senyawa bioaktif untuk bidang farmakologi. Di mana hewan ini dapat berasosiasi dengan mikroba fotosintetik dan mempunyai potensi molekular yang besar, karena kandungan metabolit sekundernya yang merupakan substansi bioaktif (Karim dkk., 2018) Menurut Macpal dkk., (2019) Ascidia adalah avertebrata laut yang mempunyai senyawa bioaktif seperti anti bakteri dan anti-UV.

Senyawa bioaktif yang disintesis oleh ascidia merupakan metabolit sekunder, yaitu metabolit turunan secara biosintetik dari metabolit primer yang digunakan dalam sistem pertahanan diri, yaitu untuk mempertahankan hidup dan menghindari gangguan dari organisme lain di lingkungan tempat hidupnya. Aktivitas farmakologinya menyebabkan senyawa tersebut memiliki prospek untuk diisolasi dan dimanfaatkan dalam bidang farmasi (Sumilat $d k k$., 2017).

Penelitian terhadap ascidia telah berkembang dengan baik, yang mengarah pada isolasi berbagai metabolit yang memiliki struktur yang unik dan memiliki senyawa bioaktivitas yang besar. Hal ini membuat ascidia memiliki potensi sebagai sumber obatobatan alami untuk mengobati berbagai penyakit, produk yang dihasilkan seperti larvasida, sitotoksik, anti jamur, anti kanker, anti inflamasi, anti virus, dan anti bakteri (Ali dan Tamilselvi, 2016)

Untuk mengetahui kemampuan dari ekstrak etil asetat dari jamur yang bersimbion dengan ascidia sebagai antibakteri dan anti-UV, maka dilakukan pengujian aktivitas anti bakteri dengan menggunakan bakteri uji $S$. aureus dan E. coli dan juga aktivitas anti-UVnya,

Senyawa antibakteri dan anti-UV yang terkandung pada jamur yang bersimbion dengan Ascidia dari Pulau Bangka, diuji apakah memiliki potensi yang dapat menghambat $E$. coli dan $S$. aureus untuk dijadikan sebagai bahan obat yang dapat digunakan untuk melindungi kulit dari paparan cahaya matahari yang berlebih, untuk itu diperlukan eksplorasi terhadap potensi anti-UV yang terdapat pada senyawa bioaktif jamur simbion ascida. Serta kurangnya penelitian tentang Anti-UV dari ekstrak jamur simbion ascidia yang telah penulis telusuri membuat penulis menjadikan salah satu alasan mengapa penulis ingin melakukan penelitian ini..

Tujuan dari penelitian ini yang pertama, Menguji aktivitas antibakteri ekstrak etil asetat isolat jamur AFBK $5 \mathrm{c}$ yang bersimbion dengan ascidia dan kedua, Membuktikan efektivitas mencegah UV ekstrak etil asetat isolat jamur AFBK $5 \mathrm{c}$ yang bersimbion dengan ascidia 


\section{METODE PENELITIAN}

\section{Waktu dan Lokasi Penelitian}

Penelitian ini dilaksanakan pada bulan Januari sampai dengan Februari 2021. Lokasi penelitian dilakukan pada dua lokasi berbeda: (1) untuk penanganan awal hingga proses pengujian anti bakteri dilaksanakan di Laboratorium Biologi Molekuler dan Farmasitika Laut, Fakultas Perikanan dan IImu Kelautan, (2) untuk pengujian Anti-UV dilaksanakan di Laboratorium Farmasi, Fakultas Matematika dan IImu Pengetahuan Alam, Universitas Sam Ratulangi, Manado.

\section{Alat dan Bahan}

Sampel yang digunakan dalam penelitian ini yaitu ascidia. Alat yang digunakan yakni: Laminar air flow, Erlenmeyer, Autoklaf, Rotary Vacuum Evaporator, Timbangan digital, Lampu Bunsen, Parafilm, Cawan petri disk, Gelas ukur, Kamera Handphone, Tabung reaksi, Mikropipet, Sarung tangan, Kertas saring/filter paper, Kertas label, Kertas alumunium foil, Masker, Jarum Ose, Pinset, Mistar, Kertas cakram/paper disc, Tisu, Corong filtrasi, Spatula, Pisau bedah, Ependorf $1.5 \mathrm{ml}$, UV-1800 spektrofotometri, Buku Tropical Pasific Invertebrates dan Ascidia in Coastal Water.

\section{Sterilisasi Alat dan Bahan}

Alat-alat dan bahan yang digunakan pertama disterilkan dahulu untuk menghindari kontaminasi. Untuk peralatan kaca seperti cawan petri, tabung reaksi dan erlenmeyer dicuci lalu dikeringkan, setelah kering selanjutnya dibungkus/ditutupi terlebih dahulu lalu disterilkan menggunakan oven pada suhu $160^{\circ} \mathrm{C}$ selama \pm 120 menit dan untuk bahan seperti media B1, PDA dan Media Nasi disterilkan menggunakan autoklaf pada suhu $121^{\circ} \mathrm{C}$ selama \pm 20 menit.

\section{Penanganan awal sampel}

Sampel yang digunakan adalah sampel yang dikoleksi dari pulau Bangka, pertama cairkan dahulu es yang menempel pada sampel tersebut, selanjutnya sampel dipotong-potong $1 \times 1$ $\mathrm{cm}$ lalu ambil menggunakan pingset dan dibilas dengan air laut steril sebanyak 3 kali kemudian rendam sampel ke dalam etanol $70 \%$ selama 1 - 2 menit untuk sterilisasi permukaan sampel, selanjutnya bilas kembali sampel menggunakan air laut saring dengan maksud untuk menghentikan proses sterilisasi permukaan sampel oleh etanol.

\section{Identifikasi Ascidia}

Ascidia yang digunakan pertamatama diidentifikasi organismenya menggunakan buku Tropical Pasific Invertebrates dan Ascidia in Coastal Water. Hal ini bertujuan untuk mengetahui spesies apa yang akan digunakan dalam penelitian ini

\section{Pembuatan Media PDA}

Media yang umum digunakan untuk menumbuhkan jamur yaitu media Potato dextrose agar (PDA). Pembuatan media PDA dimulai dengan menimbang media PDA sebanyak 3,9 gram dan 1 gram agar lalu masukan ke dalam erlenmeyer. Setelah itu tambahkan air laut saring $50 \%$ sebanyak $100 \mathrm{ml}$ selanjutnya erlenmeyer ditutup menggunakan aluminium foil dan dihomogenkan lalu disterilkan menggunakan autoklaf pada suhu $121^{\circ} \mathrm{C}$ selama 20 menit. Setelah media steril selanjutnya biarkan selama \pm 15 menit supaya saat media dituang ke dalam cawan petri tidak akan terjadi kondensasi pada tutup cawan petri, setelah itu tuang media ke dalam cawan petri.

\section{Isolasi Jamur}

Untuk mengisolasi jamur dari ascidia, pertama-tama sampel yang telah disterilkan, ditanam pada media PDA yang telah disiapkan sebelumnya dan saat melakukan penanaman harus di dalam laminar air flow untuk meminimalisir kontaminasi jamur yang tidak diperlukan. Selanjutnya tutup pinggiran petri menggunakan plastik wrap lalu diinkubasi selama 3×24 jam 


\section{Pembuatan Media Nasi}

Media nasi dibuat menggunakan beras 50 gram dan ditambahkan $60 \mathrm{ml}$ air laut saring $50 \%$ untuk 1 erlenmeyer ukuran $250 \mathrm{ml}$, selanjutnya beras dicuci bersih lalu tambahkan air laut saring 50\% setelah itu ditutup menggunakan aluminium foil dan dibiarkan semalaman. Setelah itu media disterilkan menggunakan autoklaf dengan suhu $121^{\circ} \mathrm{C}$ selama \pm 20 menit, selanjutnya inkubasi media nasi tersebut selama 1-2 hari.

\section{Kultur Jamur pada Media Nasi}

Hasil isolat murni yang telah ditanam pada media PDA selanjutnya dikultur pada media nasi dengan cara memotong-motong isolat jamur yang telah tumbuh menutupi media PDA lalu pindahkan ke dalam erlenmeyer yang berisi media nasi yang telah diinkubasi lalu diamkan hingga 14 hari hingga jamur bertumbuh memenuhi semua media nasi tersebut atau bisa juga bergantung pada pertumbuhan dari jamur tersebut.

\section{Meserasi dan Ekstrasi Jamur Simbion Ascidia}

Jamur yang telah di kultur pada media nasi selanjutnya diaduk menggunakan pengaduk kaca. Lalu dimaserasi menggunakan pelarut etil asetat sebanyak 3 kali ulangan. Setelah itu, untuk memisahkan filtrat dan debris caranya menggunakan kertas saring dan corong, setelah disaring dan mendapat filtrat selanjutnya pisahkan filtrat dengan pelarut etil asetat dengam cara pelarut akan diuapkan menggunakan evaporator pada suhu $40^{\circ} \mathrm{C}$ sehingga akan didapatkan ekstrak kasar yang akan diambil menggunakan mikroppet dan dimasukan ke dalam botol kaca kecil lalu ditutup menggunakan parafilm setelah itu diberi label.

Setelah proses inkubasi selesai, maka akan terlihat ada jamur yang tumbuh di sekitar sampel ascidia. Untuk mendapatkan isolat murni jamur, maka perlu dilakukan pemurnian lagi menggunakan media PDA dengan cara memindahkan jamur yang tumbuh di sekitar sampel menggunakan jarum ose steril ke dalam media PDA yang baru. Kegiatan ini dilakukan berulang hingga benar benar mendapatkan isolat murni pada sampel

\section{Kultur Bakteri Uji}

Bakteri uji yang digunakan diperoleh dari Laboratorium Biologi Molekuler dan Farmasitika Laut, Fakultas Perikanan dan IImu Kelautan, UNSRAT. Dan bakteri uji yang akan digunakan yaitu Staphylococcus aereus dan Escherichia coli sp.

Bakteri-bakteri yang digunakan

pertama-tama dikultur dahulu menggunakan media B1 cair. Pembuatan media B1 cair yaitu dengan melarutkan 0,25 gram pepton, 0,15 gram $\mathrm{NaCl}, 0,15$ gram meat exstract lalu larutkan menggunakan akuades $50 \mathrm{ml}$. Setelah itu media disterilkan menggunakan autoklaf pada suhu $121^{\circ} \mathrm{C}$ selama \pm 20 menit. Lalu bakteri diambil menggunakan mikropipet sebanyak 100 $\mu \mathrm{l}$ dan dimasukan ke dalam tabung reaksi yang sudah berisi media B1 cair 1 $\mathrm{ml}$ setelah itu ditutup menggunakan kapas steril dan disimpan untuk digunakan dalam proses pengujian antibakteri.

\section{Kontrol}

Pembuatan kontrol diperlukan dalam proses pengujian antibakteri karena digunakan sebagai tolak ukur untuk melihat adanya aktivitas antibakteri yang ditunjukan oleh zona beningnya. Kontrol positif menggunakan kloramfenikol sebanyak $250 \mathrm{mg}$ dan dilarutkan kedalam $250 \mathrm{ml}$ akuades di dalam Erlenmeyer dan untuk kontrol negative menggunakan etil asetat.

\section{Pengujian Antibakteri}

Media yang digunakan dalam pengujian antibakteri yaitu B1 padat. Media B1 padat dibuat dengan melarutkan 0,50 gram pepton, 0,3 gram $\mathrm{NaCl}, 0,3$ gram meat extract dan 2,00 
gram agar lalu campurkan dengan 100 $\mathrm{ml}$ akuades. selanjutnya di sterilkan menggunakan autoklaf selama \pm 20 menit pada suhu $121^{\circ} \mathrm{C}$. selanjutnya dinginkan media \pm 15 menit setelah itu masukan $1.000 \mu \mathrm{l}$ bakteri uji yang telah di kultur lalu di campurkan. Setelah itu media segera dituang ke dalam tiga cawan petri untuk tiga kali ulangan bagi masing-masing bakteri uji dan setelah itu biarkan sampai mengeras dan jika sudah mengeras selanjutnya diberi penanda pada masing-masing bakteri tersebut supaya tidak tertukar

Pengujian antibakteri akan mengguanakan metode difusi agar (Kirby-Bauer Disk Diffusion). Ekstrak jamur sebanyak 20ul ditotolkan menggunakan mikropipet pada kertas cakram. Kertas cakram yang akan dignakan berukuran $6 \mathrm{~mm}$. Pengujian antibakteri menggunakan ekstrak jamur simbion ascidia dibuat sebanyak tiga kali ulangan terhadap masing-masing bakteri untuk memastikan keakuratan data melalui pengukuran zona hambat. Pengamatan aktivitas antibakteri akan dilakukan setelah 1 × 24 jam masa inkubasi dengan cara mengamati adanya zona bening yang terbentuk disekitar kertas cakram. Jika daerah sekitar kertas cakram menunjukkan adanya aktivitas antibakteri, maka dapat dikatakan sebagai diameter zona hambat. Ukuran zona hambat akan diukur dalam satuan milimeter $(\mathrm{mm})$ menggunakan mistar berskala

\section{Pengujian Aktivitas Anti-UV}

Pengujian anti-UV dilakukan menggunakan UV spektofotometer. Alat ini digunakan untuk menguji kandungan senyawa Anti-UV pada organisme ascidia. Langkah pertama yang dilakukan yaitu larutkan $0,5 \mathrm{ml}$ ekstrak kasar jamur simbion ascidia pada $2 \mathrm{ml}$ metanol $20 \%$ setelah itu pindahkan larutan tersebut kedalam kuvet menggunakan mikropipet dan untuk perbandingannya dimasukan pelarut metanol $20 \%$ dan dijadikan sebagai blanko. Setelah itu dilakukan pengujian anti-UV dengan rentang Panjang gelombang 290-500 $\mathrm{nm}$. Setelah itu dilakukan pengamatan pada banyaknya sinar yang diabsorbsi dan ditentukan apakah nilai absorban yang dihasilkan sudah sesuai dalam senyawa anti-UV-A atau UV-B

\section{HASIL DAN PEMBAHASAN}

\section{Organisme Uji}

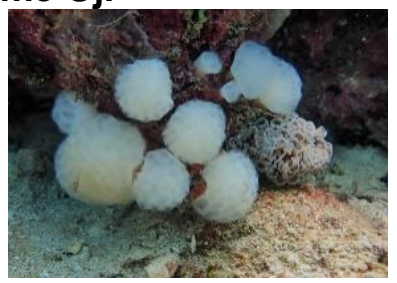

Gambar 1. Sigilina sp. (dokumentasi pribadi)

\section{Isolasi Jamur}

Hasil dari isolasi jamur pada media PDA menghasilkan isolat jamur Aspergillus sp. yang tumbuh memenuhi media PDA

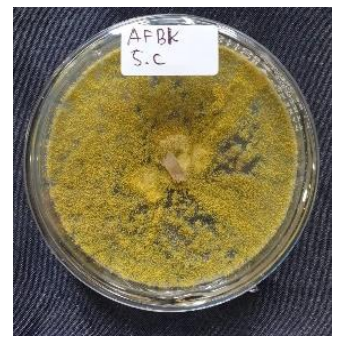

Gambar 2. Isolat murni jamur simbion Sigilina sp. (AFBK 5c)

\section{Kultur Jamur pada Media Nasi}

Hasil dari kultur jamur pada media nasi yaitu terdapat pertumbuhan isolat murni jamur memenuhi media nasi tersebut

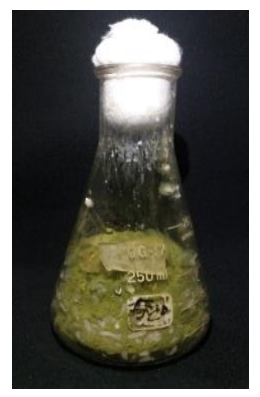

Gambar 3. Isolat Murni Jamur pada media nasi 


\section{Pengujian Antibakteri}

Setelah bakteri diinkubasi selama 1x24 jam, selanjutnya dilakukan pengamatan terhadap aktivitas antibakteri dengan bakteri uji Escherichia coli dan Staphylococcus aureus dari ekstrak kasar jamur simbion Ascida dengan kode isolat AFBK $5 \mathrm{c}$

\section{Escherichia coli}

Hasil pengamatan bakteri uji $\mathrm{E}$. Coli $1 \times 24$ jam pada ulangan $1(12,00)$, ulangan $2(0,00)$, ulangan $3(11,00)$, pada pengamatan 2x24 jam pada ulangan $1(12,00)$, ulangan $2(0,00)$, ulangan $3(11,00)$.
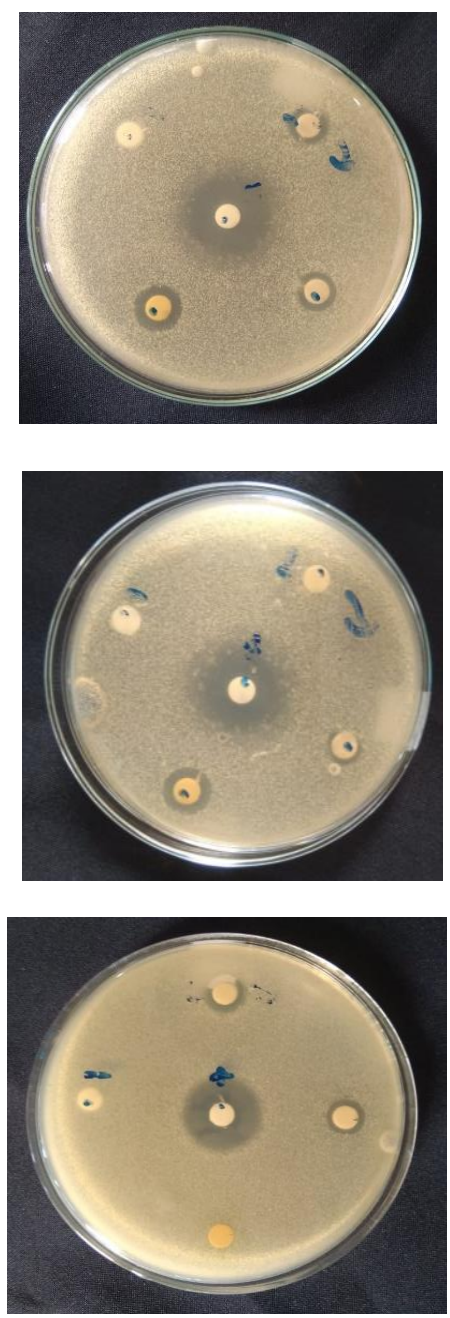

Gambar 5. Hasil pengujian antibakteri dari ekstrak kasar jamur simbion ascidia AFBK 5c pada media bakteri uji E. Coli

\section{Staphylococcus aureus}

Hasil pengamatan 1×24 jam bakteri uji $S$. aureus pada ulangan 1 $(10,00)$, ulangan $2(8,00)$, ulangan 3 $(9,00)$, dan pengamatan $2 \times 24$ jam pada ulangan $1(9,00)$, ulangan $2(8,00)$, ulangan $3(9,00)$
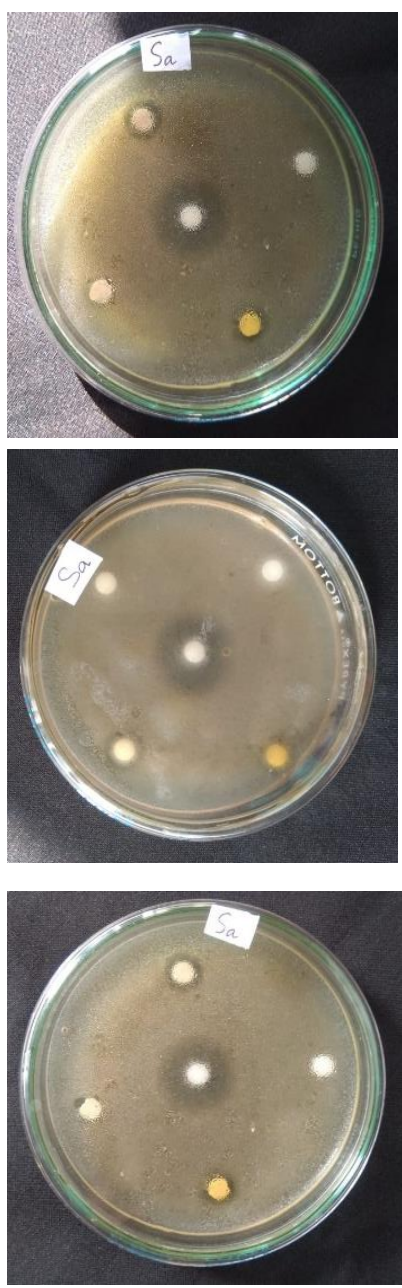

Gambar 4 Hasil pengujian antibakteri dari ekstrak kasar jamur simbion ascidia AFBK 5c pada media bakteri uji Stapilococcus sp. 
Table 1. Hasil pengujian antibakteri

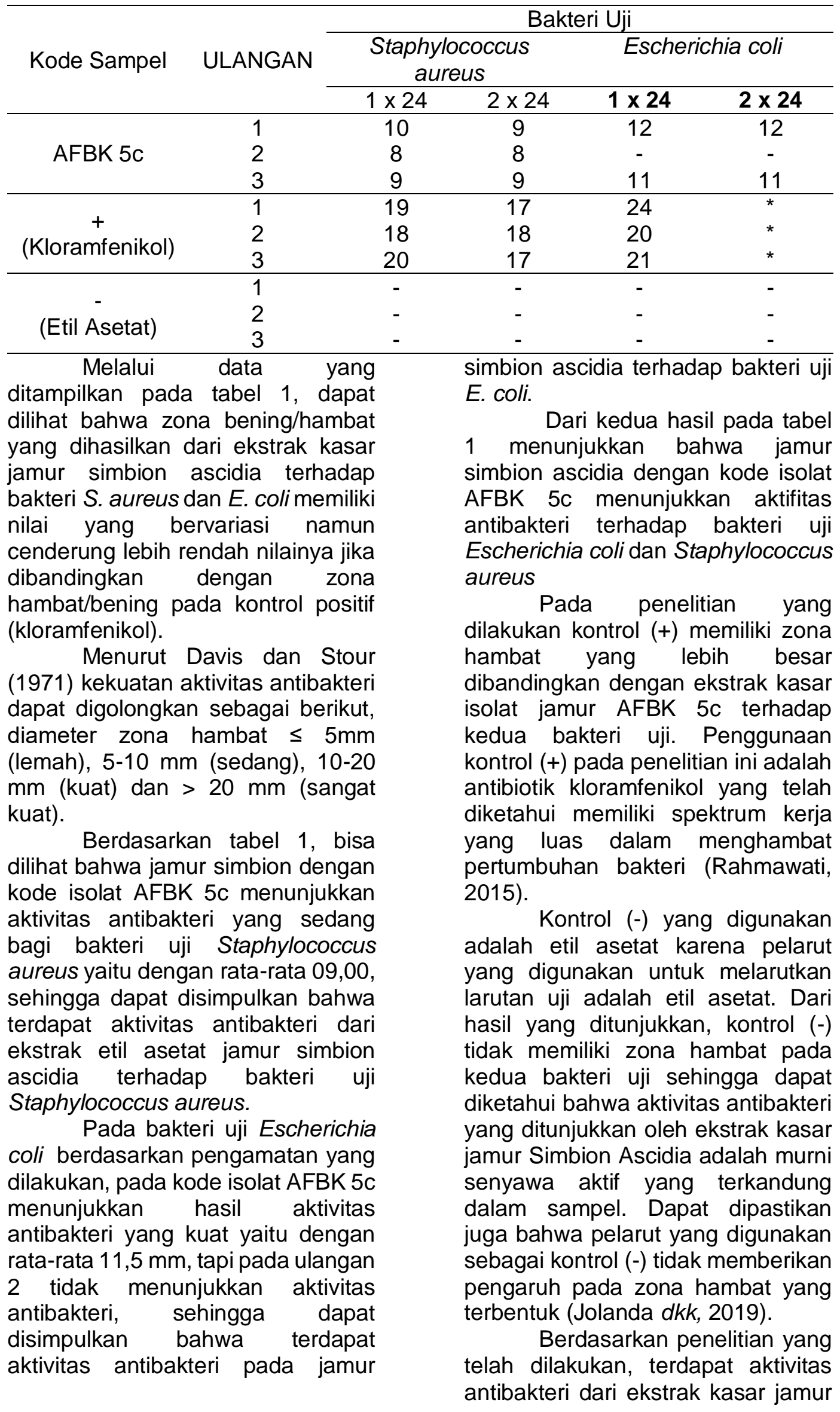


yang bersimbion dengan Sigillina sp. yang telah diuji menggunakan bakteri uji Escherichia coli dan Staphylococcus aureus berpotensi untuk dijadikan sebagai bahan obat antibakteri.

\section{Pengujian Anti-UV}

Pada pengujian anti-UV, ekstrak kasar isolat jamur AFBK 5c menunjukkan adanya serapan pada puncak pertama $\lambda$ 290-320 nm UV-B sebesar 3,5 $\AA$ selanjutnya puncak kedua juga menunjukkan adanya absorbsi UV-A $\lambda$ 320-400 nm dengan nilai absorban tertinggi sekitar $1,0 \AA$ pada $\lambda 370-400 \mathrm{~nm}$.

Menurut Tahir $d k k$, (2008) Senyawa anti-UV adalah senyawa yang memiliki paparan sinar UV A $(\lambda$ $=320-400 \mathrm{~nm})$, dan UV B $(\lambda=290$ $320 \mathrm{~nm})$, UV C $(\lambda=200-290 \mathrm{~nm})$.

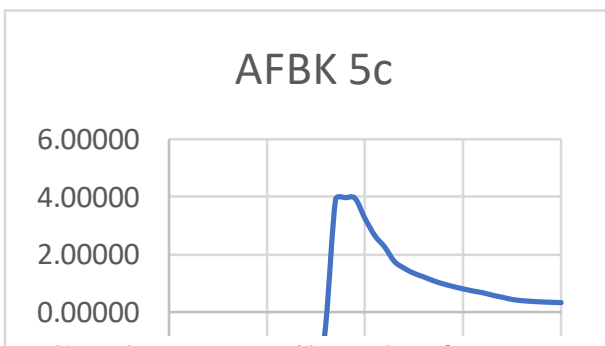

Gambar 6. Hasil spektofotometer dari esktrak estil asetat jamur simbion Ascidia dengan kode isolat AFBK 5c

\footnotetext{
Berdasarkan pengujian melalui spektofotometer menunjukkan hasil bahwa esktrak kasar jamur simbion Siggilina sp. mampu mengabsorbsi UV-A dan UV-B, untuk UV-B mendapatkan nilai absorban sebesar $3,5 \AA$ sedangkan untuk UV-A nilai serapannya bervariasi dan ada penurunan sehingga nilanya hanya sebesar $1,0 \AA$.

Sehingga berdasarkan data yang telah diuraikan diatas, esktrak etil asetat isolat jamur AFBK $5 \mathrm{c}$. menunjukkan kemampuan dalam menghasilkan senyawa anti-UV sebagai bentuk perlindungan kulit terhadap paparan sinar UV
}

\section{KESIMPULAN}

1. Terdapat aktivitas antibakteri terhadap bakteri uji Staphylococcus aureus yang ditunjukan pada zona bening yang muncul dan telah dihitung nilai rata-ratanya yaitu 9,00 dan pada Escherichia coli menunjukkan nilai rata-rata yaitu 11,05 sebagai antibakteri menggunakan bakteri uji Escherichia coli.

2. Pengujian anti-UV menggunakan spektofotometer menunjukkan bahwa sampel ekstrak kasar jamur simbion ascida dapat menghasilkan serapan pada UV-B ( $\lambda$ 290-320 $\mathrm{nm}$ ) dan dapat disimpulkan bahwa terdapat aktivitas anti-UV pada ekstrak kasar isolat jamur AFBK 5c.

\section{DAFTAR PUSTAKA}

Ali, H. A. J., \& Tamilselvi, M. 2016. Ascidians in coastal water: A comprehensive inventory of Ascidian Fauna from the Indian Coast. Springer.

https://www.springer.com/gp/b ook/9783319291178

Bara R. A., G. D. Kandou., A R. B. Ola., \& J. Posangi. 2015. Analisis Senyawa Antibiotik dari Jamur Simbion yang Terdapat dalam Ascidias Didemnum mole di Sekitar Perairan Bunaken-Sulawesi Utara. Jurnal LPPM Bidang Sains dan Teknologi. 2(2): 2835.

Jolanda, S., Wewengkang, D. S., \& Jayanto, I. 2019. Aktivitas antimikroba ekstrak dan fraksi alga (Halimeda opuntia) terhadap Escherichia coli, Staphylococcus aureus dan Candida 
albicans. Pharmacon, 8(2): 57 65.

Karim, F., Putra, Y.M., Hadi, A. T. \& Abrar, M. 2018. Antimicrobial and Cytotoxic Properties of the Ascidias Lissoclinum patella, Oxycoryna fascicularis, Didemnum molle and Botryllus schlosseri. Original article. Pharmaceutical Sciences and Research (PSR). 5 (2): 65-71.

Macpal Y., V. Warouw., D. A. Sumilat., J. J. H. Paulus. \& N. D. C. Rumampuk., dan R. L. Lreckhoff. 2019. Aktivitas Antibakteri dan Anti-UV beberapa Ascidia dari Perairan Pangalisang Bunaken. Jurnal Persisir dan Laut Tropis. 7(3): 271-285.

Marzuki, I., Noor A., Nafie N. L., dan Djide N. M. 2018. Isolasi dan Identifikasi Bakteri Simbion Spons Penghasil Enzim Amilase Asal Pantai Melawai Balikpapan. Jurnal IImiah "dr. Aloei aboe". 1 (2): 11-12

Rahmawati, M. 2015. Uji Aktivitas Antimikroba Ekstrak Etanol dan Air Rimpang Pacing (Costus spiralis) Terhadap Bakteri Escherichia coli, Shigella dysenteriae, Salmonella typhimurium, Bacillus subtilis, Staphylococcus aureus Serta Fungi Candida albicans [skripsi]. Fakultas Kedokteran dan IImu Kesehatan, Universitas Islam Negeri Syarif Hidayatullah, Jakarta. https://repository.uinjkt.ac.id/d space/bitstream/123456789/2 9205/1/MERI\%20RAHMAWA TI-FKIK.pdf

Sumilat D.A., Mewengkang D. S., Paruntu C. P. \& Rotinsulu H. 2017. Activities of Ascidia Herdmania momus on the
Colony Formation of Chinese North Sulawesi, Indonesia. Jurnal of Asean Studies and Maritime Issues. 3(5): 13-19.

Tahir, I., Wijaya, K., dan Ahmadi, A. 2008. Prediksi Tipe Aktivitas Senyawa Tabir Surya Homosalat Berdasarkan Analisis Spektra Transisi Elektronik Pada Konfigurasi Bentuk Dimer dan SolutSolven. Seminar Nasional Kimia XVIII, Yogyakarta. 